Jurnal Kesehatan Masyarakat
http://journal.unnes.ac.id/nju/index.php/kemas

\title{
HUMAN RESOURCES QUALITY AND ORGANIZATIONAL SUPPORT WITH PERFORMANCE OF HEALTH OPERATION AID FUND MANAGER
}

\author{
Semuel Delano Pehi ${ }^{\bowtie}$ \\ Postgraduate Public Health Science Program University of Nusa Cendana
}

\author{
Info Artikel \\ Article History: \\ Submitted June 2016 \\ Accepted July 2017 \\ Published July 2017 \\ Keywords: \\ Quality; Human Resources; \\ Organizational support; \\ Performance; Health Opera- \\ tional Aid \\ DOI \\ http://dx.doi.org/10.15294/ \\ kemas.v13i1. 6090
}

\begin{abstract}
Health Operational Aid Fund (HOA) is an aid to accelerate the achievement of the health-related Millennium Development Goals 2015 through improvement of primary health care performance. This study aimed to analyze relationship between quality of human resources and organizational support with performance of HOA fund manager performance. This is an explanatory quantitative study using cross section survey approach. Total sampling technique had been used to determined 48 people as the samples. Univariate analysis showed that $91.7 \%$ respondents had good performances and as many as $8.3 \%$ respondents had poor performances. Bivariate analysis showed a significant association between facilities (0.049), incentives (0.049), consulting services (0.016) and HOA fund manager performance. Multivariate analysis demonstrated a positive and significant correlation (0.043) between consultancy services and performance of HOA fund manager performance. For quality improvement, it is suggested to coordinate the public health office should better coordinate its programs via consultancy service in Plan Of of Action verification. in the consultancy service.
\end{abstract}

\section{Introduction}

Health Operational Aid (HOA) is an aid to accelerate the achievement of the healthrelated Millennium Development Goals 2015 by improving performance of primary health care. The implementation, however, have problems in every area. Performance audit reports of HOA by the Secretary of the Directorate General of Nutrition and Maternal and Child Health 2014 found problems in the implementation and accountability of HOA funds in some province and district/city due to low quality human resources (HR) and low supports of internal and external organization. This lead to an MDGs achievement where in 2013, maternal mortality rate was $346 / 100,000$ live births from the target of $102 / 100,000$ live births in 2015, the infant mortality rate was $32 / 1000$ live births from the target of 23/1000 live births in 2015, and prevalence of undernourished toddler was $19.6 \%$, higher than the target of $15.5 \%$ in 2015 .

Low quality human resources and organizational support prevent optimal management function, leading to HOA funds accountability that is performed solely for formality to meet financial administration and did not significantly improve the health program (Pani, 2011). Dasmar (2011), reported the implementation of the HOA increased the coverage of the program although it failed to reach the target of Minimum Service Standards in 2015. On the other hand, Dodo (2013), stated the implementation of the HOA in underdeveloped, border, and island region had no significant impact on the performance of the region's health system.

\footnotetext{
Correspondece Address: 
HOA implementation report of Alor Regency Health Office 2016 showed that the health program coverage in 2015 include $87.4 \%$ of $\mathrm{K} 4$ visits, $94.8 \%$ of toddler visits, $23.3 \%$ children malnutrition service, $85,2 \%$ of UCI village, public access to $\mathrm{SAB}$ of $70.1 \%$, and public access to basic sanitation amounted to $60.7 \%$. This achievement shows an increase compared to previous years despite not reaching the target of Minimum Service Standards 2015.

Implementation of the HOA in Alor District since 2010 was not free of problems that is lack of qualified human resources and the lack of organizational support from the Health Office as programs managers, local government, and society - which caused a discordance between the implementation and accountability of HOA funds and HOA Technical Guidelines, which in turn affected the low realization of HOA funds and program coverage that failed to meet the target of Minimum Service Standards 2015 . Hence, we were interested to analyze the relationship between the quality of Human Resources and organizational Support and HOA fund manager.

Method

This explanatory quantitative study used cross section survey approach in which variable for the quality of human resources, organizational supports, and HOA fund manager performance had been asked concurrently using analytic cross-sectional study design to analyze the relationship among variables through hypothesis testing according to the aim of the study. Total sampling technique defined the population of this study to be 48 people, all of which were HOA fund managers. This study took place on $1^{\text {st }}$ of February, 2016 until 23th of February, 2016. This study encompassed two variables: Independent variable, defined as the variable that is manipulated to determine the value of a dependent variable; and the dependent variable, a variable that is affected by the independent variables. The independent variables include the quality of human resources and organizational supports. The quality of human resources was measured by indicators such as: age, income, work duration, formal education, HOA knowledge, educational experience and training related to $\mathrm{HOA}$, work fidelity, work responsibilities, cooperation, and honesty at work. Organizational support was measured by indicators such as: infrastructure, labor standards, incentive, HOA consultation services, and Guidance and Control of Program Management Team. The dependent variable was the performance of the HOA fund manager measured by indicators such as: quantity of work, quality of work, timeliness in completing work, work effectiveness and efficiency, and independent work. This study used primary and secondary data. The primary data sources were the HOA fund manager as respondents and secondary data were literature or documents relevant to this study.

Primary data was collected through initial observation, structured interviews using questionnaire, and documentation, whereas secondary data was collected by literature searching, either printed media or the Internet to obtain various e-books, articles, journals, and reference sources such as the evaluation report of activities relevant to this study. Univariate analysis was used to describe the characteristics of both independent and dependent variable regarding frequency distribution and percentage. Bivariate analysis would determine the relationship between variables which was then illustrated by the $2 \times 2$ analysis table. Proportions differences test was performed using Chi Square test to prove the hypothesis as well as determining the $\mathrm{p}$ value. Last but not least, multivariate analysis was selected in this study with multiple logistic regression tests, to determine the relationship between each independent variable with the dependent variable.

\section{Result and Discussion}

Statistical analysis showed these factors of quality of human resources which include age ( $p$ value $=0.130)$, income $(p$ value $=0.649)$, work duration $(p$ value $=0.269)$, formal education ( $\mathrm{p}$ value $=0.351)$, HOA knowledge $(\mathrm{p}$ value $=$ $0.524)$, educational experience and training related to HOA ( $p$ value $=0.103$ ), fidelity of work ( $p$ value $=0.208)$, work responsibilities ( $p$ value $=0.208)$, cooperation $(\mathrm{p}$ value $=0.922)$, and honesty at work ( $\mathrm{p}$ value $=0.761$ ) was not significantly related to the performance of HOA fund manager ( $p$ value $>a(0.05)$ ). These results indicated that the quality of human resources of each HOA fund manager corresponded with 
the working standard, which provide them the capability to carry out and account for HOA appropriately according to technical guidelines. In contrast, Saputra (2015) stated the assessment of the human resources quality by assessing employees' performance showed no change in the quantity, distribution, and quality of the health worker performance. That is because this study assessed only the quality of human resources and employees in implementing and accounting HOA funds instead of using the common format of employees' performance appraisal.

Statistical analysis showed that organizational supports, which include labor standards $(\mathrm{p}$ value $=0.931)$ and Guidance and Control of Program Management Team ( $p$ value $=0.094)$, were not significantly related to performance of $\mathrm{HOA}$ fund manager ( $\mathrm{p}$ value $>a(0.05))$. These results indicated that the Department of Health gave a clear workstandards in determining the program's target and had already conducted a proper and regular coaching supervision through technical guidance and mini workshops so that the HOA fund's implementation and reporting accomplished in accordance with the guidelines even though the achievements of coverage had not reached the target of Minimum Service Standards 2015.

Statistical analysis showed that organizational support in the form of infrastructure was significantly related to performance of HOA funds manager ( $\mathrm{p}$ value $=0.049<\alpha(0.05))$. Prasastin (2012), stated that the availability of infrastructure was significantly related to employees' performance. Facilities such as computers, office supplies, and counseling contact materials was required in the implementation and timely accountability of HOA, which is a requirement used to conduct HOA performance audit. However, constraints of Department of Health's budget and the late disbursement of HOA funds led to $66.7 \%$ of respondents not receiving the infrastructure support and $25.0 \%$ of respondents receiving low quality infrastructure support. Therefore, management's function was not optimal. This means that without the support of infrastructures, HOA policy objectives may be impossible to achieve. Shortages of fund and delays in disbursement of HOA fund caused Actuating management functions to be not optimal (Mulyawan, 2012) and the performance of employees affected by the facilities such as when the work increases, employee facilities will improve the worker performance (Marimin, 2014). Facilities such as damaged computer should be repaired or replaced in order to support employee's work.

Statistical analysis showed that incentives have a significant relationship with the performance of HOA fund manager ( $\mathrm{p}$ value $=$ $0.049<\alpha(0.05))$. The results are consistent with Martcahyo's study (2012), which stated that there was positive and significant relationship between incentives and work performance. The incentive was an attempt to motivate and boost morale; however, incentives cannot be given due to HOA funds rules prohibiting incentives from being given. Instead, the Health Office allocated honorarium, however it was relatively little and was incomparable with the workload. A total of $66.7 \%$ of respondents receive honorarium in relatively small amount and $25 \%$ of respondents did not receive their honorarium in full amount. This could lead to low performance and motivation.

Statistical analysis showed that HOA consultation services had a significant relationship with the performance of $\mathrm{HOA}$ fund manager ( $p$ value $=0.016<\alpha(0.05)$ ) . The results are consistent with Zeky's study (2015), which stated that consulting services have a positive relationship in resolving third party/client's problem. The HOA Consultation services must plan its process properly and regularly, using appropriate methods to produce an excellent quality, guidelines based HOA POA. However, HOA consultation services that have been delivered were a mere formality due to lack of coordination between each program in the Department of Health and not using appropriate methods. As many as $72.9 \%$ of respondents received a good HOA consultation services although just a formality, while $18.8 \%$ of respondents did not receive good consultation service at all. This led to an implementation of HOA that failed to reach the target, although it is one of the terms used in the HOA performance audit. The planning phase of implementation of HOA funds was 
Semuel Delano Pehi / Human Resources Quality and Organizational Support

Table 1. Respondent's description according to respondent's characteristics.

\begin{tabular}{|c|c|c|c|}
\hline Characteristics & Category & $\mathrm{N}$ & $\%$ \\
\hline \multirow[t]{3}{*}{ Age } & $<20$ years old & 0 & 0 \\
\hline & 21 - 45 years old & 29 & 60.42 \\
\hline & $>46$ years old & 19 & 39.58 \\
\hline \multirow[t]{2}{*}{ Income } & $<\operatorname{Rp} 2,400,000$ & 17 & 35.42 \\
\hline & $>\operatorname{Rp} 2,400,000$ & 31 & 64.58 \\
\hline \multirow[t]{3}{*}{ Work duration } & $<5$ years & 7 & 14.60 \\
\hline & $6-20$ years & 18 & 37.50 \\
\hline & $>21$ years & 23 & 47.50 \\
\hline \multirow[t]{4}{*}{ Formal Education } & SH/SPK & 16 & 33.3 \\
\hline & Diploma I & 1 & 2.1 \\
\hline & Diploma III & 19 & 39.6 \\
\hline & Bachelor & 12 & 25.0 \\
\hline \multirow[t]{2}{*}{ HOA knowledge } & Good & 17 & 35.41 \\
\hline & $\mathrm{Bad}$ & 31 & 64.59 \\
\hline \multirow{3}{*}{$\begin{array}{l}\text { Educational experience and training related } \\
\text { to HOA }\end{array}$} & $1 \mathrm{x}$ & 4 & 8.33 \\
\hline & $2 \mathrm{x}$ & 3 & 6.25 \\
\hline & $3 \mathrm{x}$ & 41 & 85.41 \\
\hline \multirow[t]{2}{*}{ Work fidelity } & Good & 44 & 91.7 \\
\hline & $\mathrm{Bad}$ & 4 & 8.3 \\
\hline \multirow{2}{*}{ Work responsibilities } & Good & 44 & 91.7 \\
\hline & $\mathrm{Bad}$ & 4 & 8.3 \\
\hline \multirow[t]{2}{*}{ Cooperation } & Good & 35 & 72.9 \\
\hline & $\mathrm{Bad}$ & 13 & 27.1 \\
\hline \multirow[t]{2}{*}{ Honesty at work } & Good & 47 & 97.9 \\
\hline & $\mathrm{Bad}$ & 1 & 2.1 \\
\hline \multirow[t]{2}{*}{ Infrastructure } & Present & 15 & 31.2 \\
\hline & No & 33 & 68.8 \\
\hline \multirow[t]{2}{*}{ labor Standard } & Present & 23 & 47.9 \\
\hline & No & 25 & 52.1 \\
\hline \multirow[t]{2}{*}{ Incentive } & Present & 33 & 68.8 \\
\hline & No & 15 & 31.2 \\
\hline \multirow[t]{2}{*}{ HOA consulting services } & Good & 36 & 75.0 \\
\hline & $\mathrm{Bad}$ & 12 & 25.0 \\
\hline \multirow{2}{*}{$\begin{array}{l}\text { Guidance and Control of Program } \\
\text { Management Team }\end{array}$} & Good & 39 & 81.2 \\
\hline & $\mathrm{Bad}$ & 9 & 18.8 \\
\hline \multirow[t]{2}{*}{ HOA fund manager performance } & Good & 44 & 91.7 \\
\hline & $\mathrm{Bad}$ & 4 & 8.3 \\
\hline
\end{tabular}

unsuitable with the problem analysis because the support of Health Office was not optimal (Dasmar, 2011).

Results of Multiple Logistic Regression analysis showed that HOA consultation services had a positive and significant relationship with the performance of fund manager compared to the Human Resources quality and other organizational support factor $(\mathrm{p}$ value $=0.043$ $<\alpha(0.05))$. This result suggested that HOA fund manager performance, which had been audited on condition of correct target, correct time, and correct quantity, correlated with HOA consultation services in the planning, implementation, and accountability process undertaken by Health Department to the HOA fund manager. Unfortunately, HOA consultation services was a mere formality due 
Table 2. Independent and Dependent Variable

\begin{tabular}{|c|c|c|c|c|c|c|}
\hline \multirow{3}{*}{ Variable } & \multirow{3}{*}{ Category } & \multicolumn{4}{|c|}{ Performance } & \multirow{3}{*}{ P value } \\
\hline & & \multicolumn{2}{|c|}{ Good } & \multicolumn{2}{|c|}{$\mathrm{Bad}$} & \\
\hline & & $\mathrm{N}$ & $\%$ & $\mathrm{~N}$ & $\%$ & \\
\hline \multirow[t]{3}{*}{ Age } & $<20$ years old & 0 & 0 & 0 & 0 & 0.130 \\
\hline & $21-45$ years old & 28 & 58.3 & 1 & 2.1 & \\
\hline & $>46$ years old & 16 & 33.3 & 3 & 6.2 & \\
\hline \multirow[t]{2}{*}{ Income } & $<\operatorname{Rp} 2,400,000$ & 16 & 33.3 & 1 & 2.1 & 0.649 \\
\hline & $>\mathrm{Rp} 2,400,000$ & 28 & 58.3 & 3 & 6.2 & \\
\hline \multirow[t]{3}{*}{ Work duration } & $<5$ years & 6 & 12.5 & 1 & 2.1 & 0.269 \\
\hline & $6-20$ years & 18 & 37.5 & 0 & 0 & \\
\hline & $>21$ years & 20 & 47.7 & 3 & 6.2 & \\
\hline \multirow{4}{*}{ Formal Education } & SH/SPK & 14 & 29.2 & 2 & 4.2 & 0.351 \\
\hline & Diploma I & 1 & 2.139 .6 & 0 & 0 & \\
\hline & Diploma III & 19 & 20.8 & 0 & 0 & \\
\hline & Bachelor & 10 & & 2 & 4.2 & \\
\hline \multirow[t]{2}{*}{ HOA knowledge } & Good & 15 & 31.2 & 2 & 4.2 & 0.524 \\
\hline & $\mathrm{Bad}$ & 29 & 60.4 & 2 & 4.2 & \\
\hline \multirow{3}{*}{$\begin{array}{l}\text { educational experience } \\
\text { training related to HOA }\end{array}$} & once & 3 & 6.24 .2 & 1 & 2.1 & 0.103 \\
\hline & 2 times & 2 & 81.2 & 1 & 2.1 & \\
\hline & 3 times & 39 & & 2 & 4.2 & \\
\hline \multirow[t]{2}{*}{ Work fidelity } & Good & 41 & 85.4 & 3 & 6.2 & 0.208 \\
\hline & $\mathrm{Bad}$ & 3 & 6.2 & 1 & 2.1 & \\
\hline \multirow[t]{2}{*}{ work responsibilities } & Good & 41 & 85.46 .2 & 3 & 6.2 & 0.208 \\
\hline & $\mathrm{Bad}$ & 3 & & 1 & 2.1 & \\
\hline \multirow[t]{2}{*}{ Cooperation } & Good & 32 & 66.7 & 3 & 6.2 & 0,922 \\
\hline & $\mathrm{Bad}$ & 12 & 25.0 & 1 & 2.1 & \\
\hline \multirow[t]{2}{*}{ Honesty at work } & Good & 43 & 89.6 & 4 & 8.3 & 0,761 \\
\hline & $\mathrm{Bad}$ & 1 & 2.1 & 0 & 0 & \\
\hline \multirow[t]{2}{*}{ Infrastructure } & Present & 12 & 25.0 & 3 & 6.2 & 0,049 \\
\hline & No & 32 & 66.7 & 1 & 2.1 & \\
\hline \multirow[t]{2}{*}{ labor Standard } & Present & 21 & 43.8 & 2 & 4.2 & 0,931 \\
\hline & No & 23 & 47.9 & 2 & 4.2 & \\
\hline \multirow[t]{2}{*}{ Incentive } & Present & 32 & 66.7 & 1 & 2.1 & 0,049 \\
\hline & No & 12 & 25.0 & 3 & 6.2 & \\
\hline \multirow[t]{2}{*}{ HOA consulting services } & Good & 35 & 72.9 & 1 & 2.1 & 0,016 \\
\hline & $\mathrm{Bad}$ & 9 & 18.8 & 3 & 6.2 & \\
\hline Guidance and Control Program & Good & 37 & 77.1 & 2 & 4.2 & 0,094 \\
\hline Management Team & $\mathrm{Bad}$ & 7 & 14.6 & 2 & 4.2 & \\
\hline
\end{tabular}

to lack of coordination between each program in the Department of Health and not using appropriate methods so POA verification process did not proceed optimally, generating poor quality POA HOA and decreasing the performance of $\mathrm{HOA}$ fund manager.

The use of Analytic Hierarchy Process in the HOA consultation services is an approach to provide an opportunity for planners and program managers in the field of health services to generate wonderful ideas as well as to define existing problems by making assumptions to subsequently obtain the needed solution (Makkasau, 2012).

\section{Conclusion}

A total of $91.7 \%$ of HOA fund managers have a good performance. Factors significantly associated with the performance of HOA 
fund manager were infrastructure, incentives, and HOA consultation services. The most dominant positive and significant correlation was organizational support in the form of HOA consultation services. However, HOA consultation services was carried out as a mere formality due to lack of coordination between each program in the Department of Health and not using appropriate methods which in turn negatively impacted POA verification process, generating a poor quality POA that is inconsistent with the guidelines.

Related agencies including the District Health Office should make an infrastructure and incentives budget plan which is budgeted in the General Allocation Fund Unit labor, Department of Health. It is also recommended for the Program Manager to improve the coordination at every program in the Department of Health in addition to use appropriate method in verification. It is intended to make an excellent POA HOA in primary healthcare center in order to make an optimal report on funds realization and health program coverage to further give a better impact on HOA fund manager's performance.

\section{Reference}

Dasmar. 2011. Studi Evaluasi Program Dana Bantuan Operasional Kesehatan di Kabupaten Luwu. Jurnal Administrasi dan Kebijakan Kesehatan Indonesia, 02(01) : 1-7

Dodo,D.O. 2014. Monitoring Pelaksanaan Kebijakan Bantuan Operasional Kesehatan di Daerah Terpencil, Perbatasan dan Kepulauan. Jurnal Kebijakan Kesehatan Indonesia, 03 (02) :8296
Makkasau, Kasman. 2012. Efektifitas dan Efisiensi Pemanfaatan Dana Bantuan Operasional Kesehatan dengan Penerapan Metode Analytic Hierarchy Proces. Jurnal Kebijakan Kesehatan Indonesia, 01 (01) : 36-41

Martcahyo,V.A. 2012. Pengaruh Pelatihan Kerja, Jaminan Sosial dan Insentif terhadap Kinerja Karyawan Bagian Produksi PT. Fumira Semarang. Jurnal Ilmu Administrasi Bisnis, 01(01)

Marimin, Krisdiana. 2014. Pengaruh Tingkat Pendidikan, Fasilitas Kerja, dan Kepemimpinan terhadap Kinerja Pegawai Kecamatan Se-Kota Tegal. Economic Education Analysis Journal, 3 (2) : 283-289

Mulyawan, H. 2012. Evaluasi Pelaksanaan Kebijakan Bantuan Operasional Kesehatan di Dinas Kesehatan (Studi Kasus di Dinas Kesehatan Kabupaten Bantul dan Dinas Kesehatan Kabupaten Lebong. Jurnal Kebijakan Kesehatan Indonesia, 01 (03) : 144-153

Pani, M, E. 2011. Evaluasi Implementasi Kebijakan Bantuan Operasional Kesehatan di Tiga Puskesmas Kabupaten Ende Provinsi Nusa Tenggara Timur.Jurnal Kebijakan Kesehatan Indonesia, 01 (03) : 161-167

Prasastin, O. V. 2012. Faktor-faktor yang berhubungan dengan Kinerja Petugas Surveilens Epidemiologi Penyakit Malaria Tingkat Puskesmas di Kabupaten Kebumen. Unnes Journal of public Health, 02 (04): 1-1.

Saputra,M. 2015. Program Jaminan Kesehatan Nasional dari aspek Sumber Daya Manusia Pelaksana Pelayanan Kesehatan. Jurnal Kesehatan Masyarakat, 11 (1) : 32-42.

Zeky, A.A.2015. Peranan Konsultasi Konselor di Sekolah. Jurnal Tarbiyah al-Awlad, 04(02) : 426-434. 